\title{
Strategi Komunikasi Pemasaran Dalam Mempertahankan Customer Loyalty Pada Hotel Salak Bogor, Indonesia
}

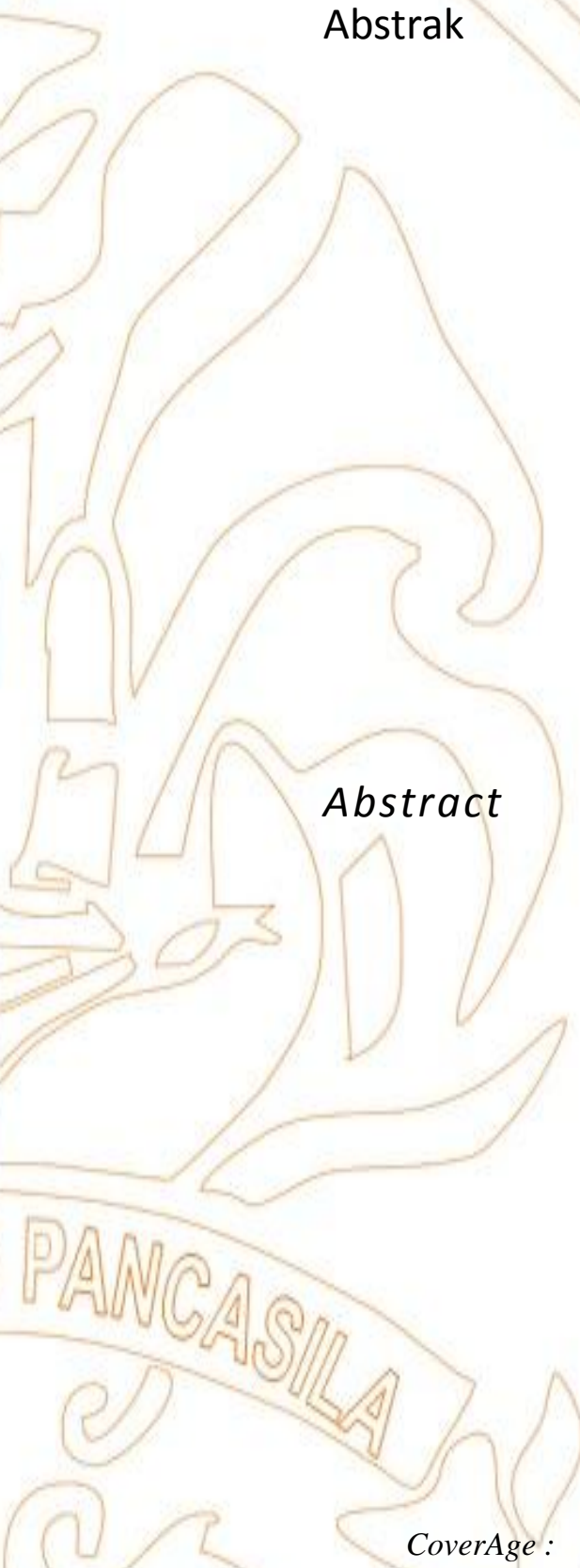

Journal of Strategic Communication Vol. 11,No. 2, Hal. 52-65

Maret 2021

Fakultas Ilmu Komunikasi, Universitas Pancasila

\section{FARIDA HARIYATI ${ }^{1}$, RINA SOVIANTI ${ }^{2}$}

${ }^{1}$ Program Studi Ilmu Komunikasi FISIP HAMKA, ${ }^{2}$ Program Studi Ilmu Komunikasi Universitas Bhayangkara Jakarta Raya Email: farida@uhamka.ac.id | rina.sovianti@dsn.ubharajaya.ac.id

Industri perhotelan atau hospitality industry menjadi bagian integratif dari sektor pariwisata di Indonesia. Penelitian ini berusaha mengkaji tentang strategi komunikasi pemasaran Hotel Salak The Heritage dalam mempertahankan customer loyalty di kota Bogor, sebagai salah satu kota pariwisata besar di Indonesia, di tengah hadirnya hotelhotel baru yang jumlahnya meningkat cukup signifikan. Penelitian ini menggunakan pendekatan kualitatif dengan metode deskriptif. Analisis data dilakukan dengan teknik triangulasi untuk meneguhkan hasil wawancara mendalam terkait dengan temuan di lapangan. Hasil penelitian ini mengungkapkan bahwa strategi komunikasi pemasaran untuk mempertahankan loyalitas pelanggan (customer loyalty) dilakukan selaras dengan identitas kultural yang melekat pada hotel ini. HSTH ditetapkan sebagai cagar budaya oleh pemerintah kota Bogor. Identitas tersebut menjadi pesan komunikasi itu sendiri, yang dimanifestasikan dalam rangkaian strategi untuk mempertahankan pelanggan. Tuntutan penggunaan teknologi juga menjadi perhatian Divisi Public Relations and Marketing HSTH untuk merancang dan mengolah pesan melalui berbagai media sosial, promosi nonmedia, dan artificial intelligent.

Kata kunci : Customer loyalty, customer repeater, komunikasi pemasaran, strategi komunikasi

Hospitality industry is an integral part of the tourism sector in Indonesia. This study aims to examine the marketing communication strategy of Hotel Salak The Heritage in maintaining customer loyalty in the city of Bogor, as one of the major tourism cities in Indonesia, amidst the presence of new hotels that have increased significantly. This study used a qualitative approach with descriptive methods. Data analysis was carried out with triangulation techniques to confirm the results of in-depth interviews related to findings in the field. The results of this study reveal that marketing communication strategies in maintaining customer loyalty are carried out in harmony with the cultural identity inherent in this hotel. HSTH was designated as a cultural preserve by the local government of Bogor. The use of technology becomes the concern for the public relations and marketing division of HSTH to design and process messages through various social media, non-media promotions, and artificial intelligent.

Keywords: Customer loyalty, customer repeater, marketing communication, communication strategy 


\section{PENDAHULUAN}

Bisnis Perhotelan menjadi bagian integratif dari sektor pariwisata di Indonesia. Hotel sebagai pilihan tempat tinggal para wisatawan baik wisatawan domestik maupun asing berlombalomba menawarkan berbagai fasilitas kenyamanan yang dapat dinikmati selama kunjungan. Indonesia sebagai negara kepulauan memiliki kekayaan destinasi wisata yang merupakan asset yang harus dimanfaatkan semaksimal mungkin untuk menopang perekonomian bangsa. Hotel merupakan hospitality industry di mana strategi komunikasi yang diterapkan mampu mempertahankan trust dan loyalitas pelanggan serta meningkatkan kepuasan para tamu. Umami (2015) mengatakan bahwa strategi komunikasi merupakan keseluruhan program dengan pesan yang disampaikan kepada konsumen atau kepada jaringan lain yang saling berkaitan dan mempunyai kepentingan yang sama.

Diantara kota-kota besar di Indonesia yang memiliki potensi pariwisata melalui bisnis perhotelan adalah kota Bogor. Bogor memiliki ciri khas cuaca yang sejuk dengan sebutan 'kota hujan', letaknya yang relatif dekat dengan Jakarta sebagai ibukota Negara, banyaknya tempat wisata bernilai historis seperti Istana Bogor, Kebun Raya Bogor, museum, tempat tempat perbelanjaan seperti factory outlet, plaza atau mall, dan tumbuhnya bisnis kuliner menjadikan Bogor memiliki potensi untuk menjadi destinasi wisata yang menarik. Daya tarik ini tentu perlu ditopang dengan penyediaan akomodasi atau tempat menginap yang mampu memberi kenyamanan bagi para pengunjung.

Seiring dengan berkembangnya jumlah hotel di kota Bogor, maka interaksi antara para pengguna jasa perhotelan semakin meningkat, oleh karenanya diperlukan strategi komunikasi melalui pendekatan tertentu antara hotel dengan publik, dalam hal ini adalah para pengunjung atau wisatawan, baik domestik maupun mancanegara. Dewasa ini, terlihat bahwa kompetisi semakin ketat dalam bisnis perhotelan, hotel-hotel berusaha menemukan cara-cara baru untuk membuat diferensiasi dan mempertahankan hubungan jangka panjang (long-term relationship) dengan para tamu (Wheeler \& Alina, 2009 dalam Demirciftci \& Kizilirmak, 2016). Loyalitas pelanggan (customer loyalty) dianggap merupakan sesuatu yang menantang dan sangat krusial dalam menentukan keberhasilan hospitality industry sebagaimana ditegaskan oleh Demirciftci dan
Kizilirmak (2016) bahwa Customer loyalty is considered challenging for hospitality industry since many alternatives have been offered by hospitality companies. As a result of this, tourists are searching for different alternatives.

Hotel Salak the Heritage Bogor yang terletak di tengah kota Bogor merupakan hotel yang memiliki keunikan dilihat dari bentuk bangunan yang memiliki nilai historis yang tetap dipertahankan sebagai salah satu icon Kota Bogor. Hotel Salak The Heritage merupakan sebuah bangunan megah bersejarah yang menjadi saksi pertumbuhan kota Bogor dari masa ke masa. Hotel Salak merupakan satu satunya hotel yang berlokasi di jantung kota, tepat berada di depan Istana Presiden Bogor, dekat dengan Balai Kota, di Jalan Ir. H. Juanda Bogor. Hotel ini dibangun pada tahun 1856 dan awalnya bernama Bellevue-Dibbets Hotel. Hotel Salak membuat distingsi sebagai hotel bagi kelompok elit dan pegawai istana. Dalam sejarahnya, hotel ini menjadi tempat pertemuan pilihan para pengusaha di bidang pertanian dan pegawai pemerintah (diolah dari company profile Hotel Salak The Heritage, www.hotelsalak.co.id). Oleh karena itu, Hotel Salak saat ini adalah hotel yang identik dengan hotel tempat pilihan untuk berbagai rapat bisnis atau pertemuan yang diselenggarakan oleh instansi pemerintah (kementerian, BUMN, pemerintah daerah, terutama yang berada di sekitar Jakarta, Jawa Barat, dan sekitarnya) dan pertemuan bisnis para pengusaha perusahaan swasta.

Bisnis perhotelan di kota Bogor semakin ketat dengan munculnya hotel-hotel berbintang, seperti hotel Santika, Amaroossa, Novotel, Aston, termasuk Hotel Salak. Persaingan usaha perhotelan yang semakin ketat ini ditunjukkan salah satu indikatornya adalah tingkat hunian kamar. Kondisi riil ini mendorong Hotel Salak The Heritage berupaya untuk membuat bermacam perencanaan program dalam rangka mempertahankan customer loyalty. Sebagai hotel yang memiliki nilai historis tinggi, Hotel Salak tetap mempertahankan identitas sejarahnya melalui bangunan lama yang tetap dipertahankan namun tetap diimbangi dengan kebutuhan aktual yang diperlukan oleh pelanggan. 


\section{TINJAUAN PUSTAKA}

\section{Strategi Komunikasi}

Cornelissen (2008:95) mengatakan bahwa mengelola komunikasi perusahaan membutuhkan suatu strategi komunikasi yang mampu menggambarkan citra umum yang menjadi tujuan perusahaan melalui pengolahan pesan-pesan kepada stakeholder. Strategi komunikasi juga memberikan panduan terhadap program komunikasi secara spesifik (seperti launching produk atau pertemuan dengan investor) (Cornelissen, 2009:95). Sementara itu, menurut Cutlip, Center, dan Broom (2009:360), dalam praktik PR, strategi mengacu kepada konsep, pendekatan, atau rencana umum untuk program yang didesain guna mencapai tujuan. Satu aspek yang melekat dengan strategi adalah taktik. Taktik mengacu kepada level operasional, yaitu kejadian aktual, media dan metode yang dipakai untuk mengimplementasikan strategi.

Menurut Effendy (2003:301), strategi komunikasi pada hakekatnya adalah perencanaan dan manajemen untuk mencapai satu tujuan. Untuk mencapai tujuan tersebut, strategi tidak berfungsi sebagai peta jalan yang hanya menunjukkan arah saja, melainkan harus menunjukkan bagaimana taktik operasionalnya. Strategi komunikasi merupakan paduan dari perencanaan komunikasi dan manajemen komunikasi untuk mencapai suatu tujuan.

Menyusun strategi komunikasi harus memperhitungkan faktor-faktor pendukung dan penghambat. Berikut ini beberapa komponen komunikasi dan faktor pendukung serta penghambat pada setiap komponen tersebut menurut Effendy (2003:35): 1) Mengenali sasaran komunikasi; 2) Faktor situasi dan kondisi; 3) Pemilihan media komunikasi; 4) Pengkajian tujuan pesan komunikasi; 5) Peranan komunikator dalam komunikasi; 6) Daya tarik sumber; dan 7) Kredibilitas sumber.

\section{Integrated Marketing Communication}

Perubahan perubahan signifikan yang terjadi dalam bidang pemasaran mendorong perusahaan untuk merubah strateginya. Kehadiran media sosial tentu saja menjadi pilihan perusahaan untuk melakukan pemasaran secara lebih efektif dan efisien. Perusahaan yang sedang menghadapi kompetisi yang ketat akan mempertimbangkan adanya strategi Integrated Marketing Communication (IMC) sebagai sebuah strategi yang menyelaraskan pesan-pesan dalam pemasaran dengan tujuan pemasaran dan target audience (Melewar et al, 2016).

Kerr et al (2008) menjelaskan bahwa IMC sebagai kunci communication tools memiliki peran yang signifikan dalam membangun kekuatan publik dan media relations. Kitchen \& De Pelsmacker (Belasen, 2008) mengatakan bahwa marketing communication merupakan kumpulan dari beberapa tema untuk fungsi-fungsi komunikasi yang digunakan dalam nilai persuasif terhadap pemasaran atau menyampaikan produk kepada pelanggan.

Menurut Duncan (Belasen, 2008), IMC adalah 'process for managing the customer relationship that drive brand value. More specifically, it is a cross-functional process for creating and nourishing profitable relationship with customers and other stakeholders by strategically controlling or influencing all messages sent to these groups and encouraging data-driven, purposeful dialogue with them'. Dari definisi tersebut dapat diinterpretasikan bahwa IMC adalah proses membangun nilai merek melalui pengelolaan hubungan baik dengan para pelanggan dengan cara mengendalikan dan mengatur strategi pesan yang dikirimkan kepada para pelanggan dan stakeholder perusahaan. Schultz \& Kitchen (2000) mengembangkan empat tahap model IMC yang mencakup: 1) Aktifitas promosi umum yang dikoordinasikan secara taktis; 2) Komunikasi yang didesain secara khusus sesuai dengan kebutuhan pelanggan dengan mendefinisikan kembali lingkup komunikasi pemasaran; 3) Mengaplikasikan strategi segmentasi untuk menerapkan teknologi informasi dan database; dan 4) Scanning dan monitoring hasil kinerja dengan bidang finansial dan tujuan-tujuan strategis.

Dalam prosesnya, Moore dan Thorson (van Riel \& Fombrun, 2007) menyarankan bahwa IMC harus diawalai dengan: 1) Mengidentifikasi seluruh target audiences yang relevan untuk mencapai tujuan pasar, 2) Segmentasi khalayak pada tahapan lingkaran keputusan pembelian, 3) Menentukan pesan dan alat-alat komunikasi untuk mencapai setiap segmen, dan 4) Mengalokasikan tingkat sumber saya secara memadai.

Sementara itu, Shimp (2014) mengatakan bahwa bentuk dasar dari komunikasi pemasaran meliputi iklan media massa tradisonal, iklan online, promosi penjualan, label pada toko dan komunikasi di tempat pembelian, brosur melalui 
direct mail, public relations dan rilis, sponsorship, presentasi, dan berbagai bentuk jaminan sebagai sarana komunikasi. Secara kolektif, berbagai sarana dan media komunikasi ini adalah hal yang secara tradisional diistilahkan sebagai promosi dalam komponen bauran pemasaran (marketing mix), yaitu produk (product), harga (price), tempat (place), dan promosi (promotion), atau dapat diistilahkan " $4 \mathrm{P}$ ".

\section{Loyalitas Pelanggan (Customer Loyalty)}

Pelanggan (customer) bagi sebuah perusahaan komersil merupakan targeted public yang harus dipertahankan terkait dengan trust dan keberlangsungan perusahaan. Customer loyalty memiliki peran signifikan dalam indikator keberhasilan sebuah perusahaan dan menjadi lebih penting ketika dikaitkan dengan keberhasilan jangka panjang. Customer loyalty merupakan tujuan utama (main objective) dalam sebuah perencanaan pemasaran karena memberikan implikasi hasil luaran (outcome) bagi perusahaan. Pertama, lebih mudah mempertahankan pelanggan daripada mencari pelanggan baru. Kedua, customer loyalty lebih menekankan pada membicarakan pengalaman penerimaan layanan di masa lalu secara positif dibanding dengan pelanggan nonloyal, di mana ada mekanisme penyebaran informasi person to person (dari mulut ke telinga). Ketiga, customer relations juga bicara soal menjamin hubungan baik antara pelanggan dengan pemberi layanan jasa. Akhirnya, pelanggan yang loyal lebih bersifat accessible daripada pelanggan baru karena perusahaan biasanya perusahaan akan membuat catatan rekam jejak pelanggan baru, membuat target market menjadi lebih memungkinkan.

Menurut Fatian dan Gholamian (Pratminingsih 2013:105), loyalitas pelanggan terjadi ketika pelanggan membeli produk atau jasa secara berulang (when a custommer buy a product or service repeatedly), dan bersikap positif terhadap barang dan jasa dari perusahaan. Selanjutnya menurut Oliver (Pratminingsih, 2013:105), ada empat tahapan dalam customer loyalty, berdasarkan pola kognisi, afeksi, dan konasi. Tahap pertama adalah cognitive loyalty. Pelanggan loyal terhadap brand berdasarkan pada informasi brand itu sendiri (customers are loyal to a brand based on their information on that brand). Tahap berikutnya adalah affective loyalty, berkaitan dengan rasa suka pelanggan (liking) atau sikap positif terhadap brand (refers to customer liking or positive attitudes toward a brand).
Tahap ketiga adalah conative loyalty or behavioural intention. Tahapan ini berkaitan dengan komitmen mendalam untuk membeli 'maksud baik' (this is a deeply held commitment to buy a "good intention"). Keinginan ini dapat menumbuhkan tindakan yang tidak disadari. Tahapan terakhir adalah action loyalty, di mana para pelanggan merubah maksud menjadi bentuk tindakan riil (where customers convert intentions into actions). Pelanggan pada tahapan ini mengalami tindakan yang mengkombinasikan dengan keinginan untuk mengatasi persoalan sehingga melakukan transaksi (pembelian atau pemesanan). Action loyalty merupakan tahapan ideal dalam customer loyalty, sehingga tidak mudah untuk mengamatinya dan mengukurnya (customers at this stage experience action inertia, coupled with a desire to overcome obstacles to make a purchase. Although action loyalty is ideal, it is difficult to observe an is often equally difficult to measure).

\section{METODE}

Penelitian ini menggunakan pendekatan kualitatif yang memiliki ciri konteks dan latar apa adanya (naturalistic), untuk mendapatkan pemahaman yang mendalam tentang sebuah fenomena (Cresswell, 2010; Denzin \& Lincoln, 2010; Guba \& Lincoln, 2010). Esensi dari penelitian kualitatif adalah memahami sesuatu yang dapat berarti banyak hal, memahami pola pikir dan sudut pandang orang lain, memahami suatu fenomena berdasarkan sudut pandang sekelompok orang atau komunitas tertentu dalam setting alamiah (Herdiansyah, 2010).

Penelitian deskripsi kualitatif ini menjelaskan tentang fenomena strategi komunikasi pemasaran melalui identitas kultural yang dipadukan dengan teknologi media yang diterapkan dalam bisnis perhotelan di Indonesia, khususnya di Bogor. Metode yang digunakan adalah studi kasus untuk menjawab permasalahan penelitian. Cresswell (2010) menyatakan bahwa studi kasus merupakan strategi penelitian di mana didalamnya peneliti menyelidiki secara cermat suatu program, peristiwa, aktivitas, proses, atau sekelompok individu. Kasus-kasus dibatasi oleh waktu dan aktivitas, dan peneliti mengumpulkan informasi secara lengkap dengan menggunakan berbagai prosedur pengumpulan data berdasarkan waktu yang telah ditentukan. Analisis data menggunakan Analisis Miles dan Huberman yang terdiri dari 
empat tahap, yaitu pengumpulan data, reduksi data, display data, dan kesimpulan atau verifikasi.

\section{HASIL DAN PEMBAHASAN}

\section{Profil Hotel Salak The Heritage}

Hotel Salak The Heritage Bogor (selanjutnya disebut HSTH) merupakan salah satu dari tujuh hotel legenda yang ada di Indonesia, di samping Hotel Royal Ambarukmo Yogyakarta yang berdiri tahun 1850, Hotel Majapahit Surabaya, berdiri tahun 1910, Hotel Savoy-Homann Bidakara Bandung yang mulai dikenal sejak penyelenggaraan Konferensi Asia Afrika pertama tahun 1955, Hotel Indonesia Kempinski, Jakarta yang berdiri tahun 1962, Inna Grand Bali Beach, Bali yang berdiri tahun 1966, merupakan hotel berstandar internasional pertama yang awalnya bernama Bali Beach Hotel. Terakhir adalah Hotel Tjampuhan \& Spa Bali, hotel ini termasuk hotel mewah di Bali, dan mulai tahun 1970an secara umum dibuka untuk melayani tamu karena pada awalnya hotel ini merupakan guesthouse yang dimiliki dan untuk melayani keluarga kerajaan di wilayah Ubud.

Sejak Tahun 1991, HSTH dikelola oleh PT Anugrah Jaya Agung berdasarkan SK Gubernur Jawa Barat No. 193/8550/Binsar tertanggal 19 Juli 1991 dan Surat Keputusan Menteri Dalam Negeri Republik Indonesia tanggal 27 Januari 1992 No. 539.32/359/PUOD untuk mengembangkan dan mengelola usaha Hotel Salak The Heritage dengan membawa bendera Salak Hospitality Group. Salak Hospitality mengelola beberapa hotel yaitu Salak Tower Hotel, The Salak Residence Inn, Salak Padjajaran Hotel, Cozzy Kostel Bogor, Vila Sawah Resort, Trizara Hotel (di Lembang, Bandung), dan yang sedang dalam proses launching Bogorienze Hotel. Selain hotel, Salak Hospitality juga memiliki Restoran Klappertaart Huize, dan Bogor Hotel Institute (BHI). Dalam perjalanannya, HSTH mengalami dinamika dalam pengelolaan dan operasionalisasi bisnisnya.

Berdiri pada tahun 1856 dengan nama Bellevue-Dibbets Hotel, hotel ini merupakan bangunan bersejarah yang memiliki nilai prestisius dan menjadi saksi sejarah perkembangan Kota Bogor. HSTH merupakan satu-satunya hotel legendaris yang berdiri megah di jantung Kota Bogor, berada di depan Istana Bogor, dan bersebelahan dengan Kantor Walikota, berlokasi di Jalan Ir. H. Juanda Nomor 8 Bogor. BellevueDibbets Hotel pada awalnya membuat distingsi menjadi hotel tempat pertemuan para elit dan anggota istana. Pada tahun 1998, Hotel ini beralih nama menjadi HSTH dan mendeklarasikan diri memiliki daya tarik internasional (international appeal). HSTH memiliki motto atau tagline:"Where Historical Values and Modern Technology Meet". Artinya bahwa HSTH merupakan sebuah tempat dengan nilai-nilai historis dan didukung oleh teknologi terbaru

Pencapaian HSTH dalam menciptakan sentra konferensi yang unggul (excellent conference center) dalam bidang MICE (Meeting, Incentive, Convention \& Exhibition) dibuktikan dengan meningkatnya permintaan untuk menggunakan fasilitas HSTH untuk pelatihan, pertemuan (rapat), dan seminar. Dalam rangka mengantisipasi pertumbuhan sektor pariwisata, permintaan pelanggan yang cukup tinggi, dan perkembangan pasar, maka HSTH menambah unit kamar dari 32 menjadi 140 unit kamar dalam berbagai tipe.

HSTH memiliki dua unit kamar Presidential Suite, empat kamar Super Executive, delapan Kamar Executive, empat kamar Deluxe Suite, 47 kamar Deluxe, 53 kamar Superior, 20 kamar Standar, dan 16 ruang pertemuan. Ruang pertemuan yang tersedia adalah Istana Ballroom, Galuh, Batu Tulis I, II, III, dan IV, Burangrang, Pakuan, Padjajaran I, II, dan III, Ruang Kinanti, Kujang I dan II, Ruang Istana untuk pertemuan ukuran kecil, dan Arcade. HSTH juga menawarkan berbagai fasilitas seperti fitness center, Restoran Fatmawati, Café Den Haag, Herb \& Herbal Place, Binnenhof Restaurant, Bellevue Wellness Salon \& Spa, Bellevue Barber Shop, tempat bermain anakanak, kolam renang, Kanari Café, Rafflesia Lounge, pusat bisnis, dokter gigi, dan toko obat.

\section{Hasil dan Pembahasan}

Dewasa ini, perusahaan perusahaan, termasuk hospitality industry menghadapi era persaingan yang sangat ketat. Namun demikian, dengan beralih dari filosofi produk dan penjualan ke filosofi holistik, perusahaan akan mendapatkan peluang yang lebih baik untuk memenangkan persaingan (Kotler \& Keller, 2012:133).

Hotel Salak The Heritage (Hotel Salak) telah menjalankan bisnisnya dalam kurun waktu yang lama. Sebelum tahun 1998, Hotel ini dikelola oleh Pemerintah Kota Bogor dengan nama Hotel Salak, dan sejak September 1998 hingga sekarang, pengelolaan Hotel Salak diserahkan kepada PT Anugrah Jaya Agung, dengan perjanjian sistem sewa tanah dengan Pemkot Bogor. Dalam 
kesepakatan tersebut disebutkan bahwa bagian depan bangunan yaitu Collonial Building yang merupakan bangunan asli peninggalan zaman kolonial Belanda harus dipertahankan bentuk aslinya dan tidak diperkenankan dipugar.

Rancangan strategi komunikasi melalui promosi terutama untuk mencapai target dalam revenue bidang MICE (meeting, incentive, convention, exhibition) dilakukan oleh bagian PR dalam bagian ini memiliki beberapa spesialis yang menjalankan fungsinya masing-masing, yaitu:

1. Content \& Digital Specialist; bertugas membuat konten media sosial. Bagian ini bekerjasama dengan social media specialist untuk menentukan konten media sosial sesuai dengan special event yang dijadwalkan.

2. Social media specialist; bagian ini me-maintain dan menjadi administrasi media sosial yang dimiliki HSTH. Media sosial yang digunakan untuk mem-blasting informasi terkait promosi adalah Facebook, Instagram, dan Twitter.

3. Hotel Artist; berfungsi untuk merancang desain-desain tools terkait special event, misalnya logo event, banner, flyer, properti ruangan terkait hari besar atau hari raya, termasuk merancang desain ruang makan dan lain-lain terkait promosi

4. Guest Relations Officer; berperan dalam menjalin hubungan baik dengan para tamu hotel, seperti me-maintain complain tamu, memberikan informasi yang dibutuhkan tamu, melakukan review atas kepuasan para tamu atau pelanggan.

\section{Strategi Komunikasi Pemasaran dalam Mempertahankan Loyalitas Pelanggan}

Berdasarkan hasil wawancara dengan PR Coordinator, Adysti Fristiana, maka ditemukan bahwa strategi komunikasi dan pemasaran dirancang dan dilakukan secara kolaboratif antara bagian PR \& Promotion dan Marketing secara keseluruhan. Faktor-faktor yang menjadi titik penguat promosi HSTH berkaitan dengan identitas kultural perusahaan adalah:

1. Hotel Salak ditetapkan sebagai salah satu cagar budaya Kota Bogor oleh Pemerintah Kota Bogor. Sebagai konsekuensinya adalah bahwa bangunan utama HSTH yang disebut Collonial Heritage Building tidak diperkenankan untuk dirubah bentuknya, sehingga bangunan ini tetap dipertahankan, hanya direnovasi untuk memperkuat bangunan.
2. Posisi strategis HSTH berada di titik nol Kota Bogor, atau disebut ring satu. Di depan HSTH adalah Istana Bogor yang kerap menjadi venue acara penting yang bersifat kenegaraan dan sebagian tamu akan menginap di HSTH.

3. Segmen pelanggan tetap mengarah pada MICE, hal ini tentu tidak terlepas dari distingsi Hotel Salak di masa lalu sebagai tempat bertemunya para pejabat masa kolonial Belanda. Para pelanggan Hotel Salak utamanya adalah corporate, baik pemerintah maupun swasta. Sehingga hotel ini mengalami suasana ramai pada saat weekdays, sementara pada saat akhir pekan pengunjung tidak ramai. Seperti diungkapkan oleh Adhysti, Koordinator PR:

"segmen pelanggan kita lebih ke
MICE sih, karena hotel kita untuk
meeting-conference, makanya kita
sibuknya di weekdays, bukan
weekend. Jadi kalau weekdays
pasti penuh. Pelanggan biasanya
dari kementerian atau lembaga
pemerintah, dari corporate
(perusahaan) yang berasal dari
Jakarta dan sekitarnya (Jawa Barat
utamanya)."

Terkait dengan rancangan penentuan strategi komunikasi bagian PR bekerjasama dengan bagian Marketing. Diawali dengan meeting yang dilakukan mingguan, yaitu setiap hari Senin. Dari hasil pertemuan mingguan tersebut akan diputuskan program dan kegiatan yang dilakukan oleh PR dan Marketing. Jadi program tidak dirancang untuk setahun ke depan dari awal tahun, namun pihak manajemen Hotel Salak lebih menerapkan pertemuan mingguan untuk efektivitas dan mudahnya perancangan acara karena event penting terkadang tidak masuk dalam agenda namun dapat bersifat incidental, misalnya acara kenegaraan di Istana Bogor yang kemudian implikasinya adalah meminta Hotel Salak untuk segera merancang acara terkait.

Menciptakan pelanggan yang loyal adalah inti dari setiap bisnis. Don Peppers dan Martha Rogers (Kotler \& Keller, 2012:134) mengatakan bahwa "satu-satunya nilai yang dapat diciptakan perusahaan adalah nilai yang berasal dari pelanggan-yakni nilai yang dimiliki sekarang dan nilai yang akan dimiliki di masa depan. Suatu bisnis disebut sukses jika berhasil mendapatkan, mempertahankan, dan menumbuhkan pelanggan. Pelanggan merupakan satu-satunya alasan perusahaan mengembangkan usaha, 
mempekerjakan karyawan, menyusun agenda pertemuan, dan melibatkan diri dalam aktivitas apapun. Tanpa pelanggan, perusahaan tidak akan memiliki bisnis."

Bagi HSTH, pelanggan yang loyal menjadi target utama dalam menjalankan bisnisnya. Menurut Adhysti, dalam wawancara menyebutkan bahwa ketika bicara tentang loyalitas, maka bagi HSTH adalah para repeater yaitu pelanggan yang mengulang dalam menggunakan layanan hotel. Hal ini menjadi perhatian utama HSTH, mengingat kompetitor dalam bisnis hospitality industry di Bogor semakin ketat.

\section{Komponen dalam Strategi Komunikasi HSTH}

Secara umum, bagian PR dan Promotion HSTH melakukan strategi untuk menarik dan sekaligus mempertahankan loyalitas pelanggan dengan fokus pada pemilihan media (saluran komunikasi), special event, dan artificial intelligent. Untuk menguraikan strategi komunikasi, maka beberapa komponen yang menjadi perhatian HSTH adalah:

\section{Mengenali Sasaran Komunikasi}

Sasaran komunikasi di sini adalah segmentasi pelanggan (customer) dari HSTH. Segmentasi ini diperlukan agar dalam penyusunan pesanpesan dari perusahaan menjadi lebih efektif kepada khalayak sasaran dan efisien karena perusahaan telah melakukan seleksi segmen pelanggan dan memahami karakter pelanggan. Pelanggan HSTH di bagi menjadi dua kelompok yang meliputi FIT (Free Individual Travellers) termasuk pelanggan keluarga (family), dan Corporate Group yaitu dari lembaga atau instansi yang menggunakan jasa MICE (meeting, incentives, conference, and exhibition) di HSTH. Dalam masing-masing kategori pelanggan, Divisi Marketing HSTH memiliki bagian khusus yaitu FIT Specialist dan Group Specialist. Target dari FIT Specialist adalah menarik perhatian dari pengunjung nongroup, yakni individual dan keluarga yang menginap di HSTH dengan memberikan promosi yang bersifat special event yang bersifat tematik, misalnya tahun baru, liburan sekolah, dan hari raya keagamaan. Misalnya tahun 2017 memilih tema untuk promo akhir tahun adalah carnival yang memiliki makna having fun dan keramaian dengan menampilkan banyak pertunjukan hiburan dan permainan. Tahun 2018 memilih tema akhir tahun yaitu lullaby yang ditujukan untuk menarik tamu-tamu kelompok family, yakni mengadakan permainan bagi anggota keluarga yang diadakan di area kolam renang setiap akhir minggu dengan tema wet wet party. Pergantian tema dalam dua tahun tersebut tentu melalui proses evaluasi. Menurut PR HSTH, Adhysti, pergantian tema dilihat dari keterlibatan tamu-tamu, jika carnival lebih banyak ditujukan dan diikuti tamu-tamu dewasa sehingga untuk anak-anak kurang dapat mengikuti acara karena tidak sesuai dengan usia mereka. Dengan proses evaluasi tersebut, maka tahun 2018 dirubah tema dengan harapan dapat mengakomodir semua kelompok tamu, baik dewasa, remaja, maupun anak-anak.

\section{Faktor Situasi dan Kondisi}

Situasi dan kondisi merupakan faktor internal dan eksternal di mana sebuah aktivitas komunikasi terjadi. Dalam kaitan dengan strategi komunikasi yang dijalankan oleh HSTH adalah faktor eksternal perusahaan yang kemudian mempengaruhi perencanaan dan implementasi strategi tersebut. Faktor eksternal yang cukup penting untuk diperhatikan adalah tingkat kompetisi dalam industri perhotelan khususnya di Bogor semakin kuat. Dalam lima tahun terakhir ini, pertumbuhan hotel-hotel di Bogor mengalami peningkatan jumlah yang pesat, sebagaimana yang disampaikan oleh PR HSTH, Adhysti :

"Di Bogor ini pertumbuhan hotel baru cukup pesat, dalam setahun bisa muncul 5 hotel seperti Novotel, Amarosa, Santika, Ibis, Aston dan lain-lain. Selain itu juga munculnya budget hotel (hotel dengan rate rendah) menjadi tantangan tersendiri buat Hotel Salak... karena customer terkadang hanya fokus pada harga, namun tidak memperhatikan hotel berbintang atau tidak..."

\section{Pemilihan Media Komunikasi}

Pemilihan saluran atau media merupakan bagian dari strategi komunikasi perusahaan untuk efektivitas pesan sampai kepada para khalayak. Dalam implementasi strategi komunikasi HSTH, media yang digunakan untuk mempromosikan HSTH diantaranya adalah:

a Electronic Blasting. Electronic blaster berperan dalam mengirimkan informasi melalui mailing list dan email. Strategi ini adalah menjadi reminder, yakni 
mengirimkan email kepada para pelanggan terkait dengan promo dan event khusus yang diadakan oleh hotel dengan harapan para pelanggan datang kembali ke Hotel Salak. Email yang dikirim berupa digital flyer berkaitan dengan paket promo atau event khusus melalui alamat email marketing@hotelsalak.co.id.

b Sebagian besar tools yang dibuat oleh PR \& Pomotion sudah berbentuk digital, jadi sudah membatasi untuk membuat tools yang berwujud fisik (printed). Hal ini dilakukan sebagai implikasi dari tag line "Where historical values and modern technology meet". Email blasting juga digunakan oleh bagian Guest Relations Officer sebagai media untuk mengirimkan apologize letter atas ketidaknyamanan yang mungkin dialami oleh pelanggan misalnya kerusakan pada fasilitas kamar (AC, kamar mandi, tempat tidur, jaringan internet, kehilangan barang dan lain-lain).

c Media Sosial. Tak dapat dipungkiri bahwa media sosial menjadi media yang efektif untuk memberikan informasi terkait berbagai event yang diselenggarakan oleh pihak hotel dengan lebih efektif dan efisien. Media sosial yang dimiliki Hotel Salak adalah akun Instagram @hotelsalak; Facebook Hotel Salak, dan Twitter @HotelSalak. Untuk event akhir tahun, bagian PR dan Marketing merancang acara yang dikemas juga untuk keluarga.

d SMS Blaster. Bagian ini bertugas untuk mengirimkan SMS (short message service) kepada pelanggan. SMS dikirimkan kepada pelanggan berdasar database pelanggan yang masuk melalui front office ataupun check in online. Seperti halnya media lain yang digunakan, SMS blasting juga bertujuan untuk reminder kepada pelanggan, pesan SMS berisi penawaranpenawaran menarik dan promo terkait harihari penting yang mungkin menarik minat pelanggan.

e Platform e-Commerce. Sebagai bentuk pelayanan pelanggan di era digital, Hotel Salak juga memutuskan untuk memberikan layanan pelanggan melalui platform $e$ commerce. Mekanisme e-commerce di Hotel Salak menjadi tanggung jawab bagian E-Commerce Specialist di bawah Marketing. Pihak Hotel Salak memberikan kebijakan khusus terkait dengan e-commerce bagi pelanggan yakni berkaitan dengan rate harga yang di publish melalui platform. Hotel Salak memutuskan untuk fokus pada satu platform saja dengan memiliki kontrak eksklusif dengan Traveloka. Hal ini disebabkan karena mekanisme pembayaran di Traveloka lebih memberikan peluang untuk terjadinya transaksi dari pelanggan, di banding dengan platform yang lain seperti booking.com yang memungkinkan terjadi pembatalan booking sebelum terjadinya transaksi.

f Media massa konvensional, seperti majalah, surat kabar, radio, dan televisi untuk program-program tertentu untuk iklan dan promosi berbagai event khusus atau atas undangan dan permintaan dari media yang bersangkutan.

g Strategi Komunikasi melalui special events dilakukan melalui beberapa kegiatan yakni:

1 Annual Event. Annual event yaitu promo event yang diadakan tahunan dengan tema-tema yang berganti seperti, seperti promo dalam rangka Hari Raya Idul Fitri, Hari Natal, Hari Nasional, tahun baru dan liburan sekolah, yakni dengan memberikan penawaran khusus selama hari besar tersebut dalam jangka waktu tertentu. Pada event akhir tahun 2018 ini, Hotel Salak memberikan promo untuk event Natal dan Tahun baru yaitu melalui wonderful christmast package dan lullaby slumber. Keduanya ditujukan untuk memeriahkan event Hari Natal dan Tahun Baru 2019 yang ditujukan bagi pengunjung kelompok keluarga (family) atau disebut Free Individual Traveler (FIT), meskipun target utama pelanggan adalah corporate untuk MICE. Untuk event akhir pekan bagi keluarga, Hotel Salak memiliki program wet wet party, yaitu acara yang digelar di kolam renang untuk anak-anak yakni dengan game dan pembagian hadiah.

2 Incidental Events. Event ini dilakukan ketika ada permintaan khusus dari pemerintah baik daerah maupun pusat, misalnya terkait dengan kunjungan pemimpin negara asing, presiden, atau pejabat di tingkat kementerian, maupun konferensi atau pertemuan tingkat regional dan internasional, dan Hotel Salak dipilih menjadi venue atau bagian dari pelayanan akomodasi para delegasi dan peserta. 
3 Kegiatan Asosiasi. Kegiatan promosi juga dilakukan melalui Indonesia Hotel General Manager Association (IHGMA), yakni asosiasi para General Manager Hotel Indonesia, misalnya kegiatan charity untuk masyarakat sekitar hotel berada dan pemberian donasi, seperti yang dilakukan untuk korban Gempa di Palu.

4 Strategi komunikasi melalui Artifical Intelligent. Selain melalui media dan special events, HSTH telah menerapkan artificial intelligent berupa Robot Raisa yang difungsikan untuk membantu para tamu yang menginginkan informasi seputar hotel. Tamu akan melihat cara penggunaan robot ini melalui petunjuk yang ada pada robot tersebut. Robot Raisa ini diletakkan di lobi dan sekaligus membantu bagian Guest Relations Officer (GRO) untuk memberikan pelayanan kepada para tamu. Robot Raisa baru diaplikasikan di beberapa perusahaan di bawah Salak Hospitality, yakni HSTH, Salak Tower Hotel, Klappertaart Huize, dan Bogor Hotel Institute.

\section{Pengkajian Tujuan Pesan Komunikasi}

Strategi komunikasi yang dikemas melalui pesan-pesan marketing dan promosi HSTH memiliki tujuan yang hendak dicapai oleh HSTH yakni meningkatkan revenue dalam setiap tahunnya. Seperti telah dibahas dalam faktor situasi dan kondisi di mana realitas persaingan dalam industri perhotelan yang semakin ketat khususnya di Bogor, maka pihak PR \& Promotion bersinergi dengan bagian Marketing untuk menyusun pesan-pesan promosi yang dilakukan melalui divisi-divisi spesialis yang fokus pada bidang masing-masing, yaitu social media specialist, content specialist, dan hotel artist. Penentuan program dan kegiatan promosi diputuskan dalam pertemuan rutin semua divisi yang dilakukan seminggu sekali setiap hari Senin. Perencanaan dilakukan melalui mekanisme meeting pihak manajemen, seperti yang disampaikan Firdy, bagian HRD Management:

"Untuk merancang biasanya ada meeting tingkat manajemen, jadi dari pihak atasan memberi tau apa yang harus kita rancang untuk event atau acara tertentu. Dari meeting itu akan muncul ide-ide baru, khusus $P R$ dari segi promosi seperti apa, jadi programnya di-update mingguan, misal menjelang awal tahun kita juga rancang mingguan, atau menjelang akhir tahun kita evaluasi atau review program tahun kemaren untuk dibuat program yang baru."

Kajian terhadap pengolahan pesan khususnya bagian PR \& Promotion dan Marketing tentu bermuara pada tujuan HSTH, yaitu mengedepankan prinsip fairness, kejujuran, dan integritas bersama pelanggan (customer), supplier dan para karyawan; serta untuk pertumbuhan tujuan jangka panjang, profit dan pengakuan sebagai perusahaan yang berkualitas dan inovatif.

\section{Peran Komunikator dalam Komunikasi}

Memberikan pelayanan terbaik kepada pelanggan merupakan keharusan bagi perusahaan profit seperti HSTH. Peran komunikator perusahaan menjadi sangat penting terkait dengan menjaga reputasi yang telah dimilikinya. Dalam konteks strategi komunikasi HSTH, Divisi PR \& Promotion dan Marketing menjadi bagian pengolah pesan dalam kaitannya dengan penjualan layanan jasa perhotelan, termasuk bagaimana merespon secara cepat keluhan pelanggan yang dilakukan oleh Guest Relations Officer (GRO) dengan memberikan apologize letter kepada pelanggan sesaat setelah check out; juga melayani lost and found, yakni keluhan kehilangan barang-barang milik tamu, sebagaimana yang diungkapkan oleh Adhysti dan Firdy:

"Bagian PR ini kalo untuk promosi, tapi kita punya specialist-spesialist sendiri, seperti Social Media Specialist dan Content Specialist yang berkoordinasi untuk membuat konten media sosial di Instagram, Facebook, Twitter, apa yang akan diposting setiap harinya. Kita juga memiliki hotel artist, untuk mendesain misal paket-paket promosi, desain logo, logo event, banner, termasuk desain tata letak buffet makanan dan minuman. Selain itu kita juga punya GRO (Guest Relations Officer), bagian $P R$ di depan yang tugasnya memaintain keluhan dan kemudian di 
follow up, misal soal fasilitas kamar, misal AC panas. Kemudian GRO merespon dengan cara mengirimkan email apologize letter, juga lost and found, misal ada barang ketinggalan maka akan dihubungi pemilik dan dikirimkan ke alamatnya"

\section{Daya Tarik Sumber}

Daya tarik dapat dipahami sebagai nilai distingsi atau pembeda perusahaan yang tidak dimiliki oleh organisasi atau perusahaan lain. HSTH merupakan hotel tertua di Bogor dan memiliki nilai historis yang cukup kuat dilihat dari arsitek bangunan lama di bagian depan yaitu collonial building yang dipertahankan bentuk aslinya dan menjadi daya tarik para tamu dan wisatawan sekaligus ditetapkan sebagai salah satu cagar budaya oleh Pemerintah Kota Bogor. Konsep bisnis HSTH adalah tourism and business hotel dengan mengikuti standar internasional. Karena keunikan bangunannya maka hotel ini diarahkan sebagai boutique hotel untuk tamutamu wisatawan khusus dan para ekspatriat. Collonial building menjadi satu-satunya bangunan hotel bersejarah yang tersisa di Kota Bogor, dan bagian hotel yang dikembangkan adalah di bagian belakang yang diarahkan menjadi business and university hotel. Selain dari aspek bangunan, daya Tarik HSTH adalah menu unggulan yang menjadi favorit tamu khususnya tamu dari mancanegara, yakni oxtail soup, di mana menu ini adalah menu legendaris karena telah dikenal sejak masa kolonial dan terus dipertahankan hingga sekarang.

\section{Kredibilitas Sumber}

Kredibilitas merupakan karakteristik yang dikaitkan dengan individu, institusi, ataupun produk komunikatif. Kredibilitas HSTH dapat dilihat dari target market dalam segmentasi pengunjung dari kelompok corporate, yaitu perusahaan atau instansi yang membutuhkan fasilitas ruang pertemuan dari skala besar, sedang, dan kecil untuk acara-acara seperti konferensi, rapat, seminar, atau pernikahan. Seperti yang diungkapkan Cindy, bagian pemasaran:

"peluang kita tetap pada MICE karena di situ kekuatan (strength) hotel kami. Kita tetap memakai MICE, misal seperti ruang conference yang bisa menampung peserta dalam jumlah besar. Atau misal peserta dibagi dalam ruangruang kecil, kita punya semua jenis ruang pertemuan dari yang besar sampai yang kecil. Kita punya 14 meeting room, 2 ballroom yang bisa menampung 500 orang, kalua untuk wedding bisa sampai 1000 pax. Yang seperti ini kami maintain betul oleh marketing dan sales call untuk mengkomunikasikan dengan pelanggan".

\section{Model Strategi Komunikasi dan Promosi HSTH}

Sebagaimana tercantum dalam motto HSTH, yaitu "Where Historical Values and Modern Technology Meet", maka strategi komunikasi yang dilakukan oleh HSTH pun selaras dengan motto HSTH itu sendiri. Nilai-nilai sejarah menjadi penciri atau distingsi bagi HSTH yang tidak dapat ditinggalkan sebagai salah satu tempat peninggalan zaman kolonial, dan ditunjukkan dengan bangunan asli (collonial building) yang menjadi wajah utama HSTH untuk menarik para tamu dan wisatawan. Tidak hanya bangunan yang menjadi penciri, namun diikuti pula dengan posisi atau letak geografis HSTH yang cukup strategis, yaitu di titik nol Kota Bogor. Selain itu posisi strategis diperkuat dengan letak yang berdekatan dengan Istana Bogor, yang juga menjadi tempat wisata, sekaligus tempat untuk beberapa acara kenegaraan atau kepresidenan. Selanjutnya, nilai kultural yang dimiliki HSTH juga ditunjang dengan penyediaan menu tradisional dan legendaris, seperti oxtail soup, klapeertart (makanan khas dari negara Belanda), dan ayam goreng Fatmawati.

Namun demikian, tidak dapat dipungkiri bahwa saat ini kompetisi bisnis perhotelan semakin ketat dengan menawarkan variasi harga dan fasilitas yang modern. Hal ini tentu menjadi perhatian dan mendorong HSTH juga merespon secara cepat dengan berbagai perencanaan strategis, seperti mengembangkan penyediaan kamar-kamar dengan harga setara dengan budget hotel (hotel dengan rate rendah), karena wisatawan yang datang ke Kota Bogor terdiri dari berbagai kelompok, dari kelas bawah, menengah, hingga kelas atas. Penggunaan media sosial seperti Instagram, Facebook, dan Twitter tidak dapat dihindari mengingat saat ini terjadi transformasi dalam pemilihan saluran komunikasi oleh perusahaan untuk menjangkau publik secara lebih luas dan waktu yang relative lebih singkat. 
Perubahan tren dalam mekanisme booking hotel saat ini juga menjadi pertimbangan HSTH untuk menggunakan platform e-commerce dalam pelayanan kepada pelanggan, yaitu melalui platform Traveloka. Sentuhan teknologi yang juga menjadi saluran penyampaian pesan-pesan promotive bagi HSTH adalah melalui electronic blaster, yaitu email, mailing list, dan SMS blasting yang masih cukup efektif menjangkau pelanggan. Satu aspek teknologi modern yang diterapkan oleh HSTH adalah disediakannya Robot Raisha sebagai implementasi artificial intelligent untuk membantu memberikan informasi bagi tamu terkait ruangan atau lokasi yang dibutuhkan pelanggan di area hotel, dengan mengikuti petunjuk yang telah disediakan.

Secara garis besar, model strategi komunikasi pemasaran dan promosi dalam rangka mempertahankan loyalitas pelanggan di Hotel Salak dapat digambarkan dalam bagan berikut:

\section{Gambar 4.1}

Strategi Komunikasi Hotel Salak dalam Mempertahankan Customer Loyalty

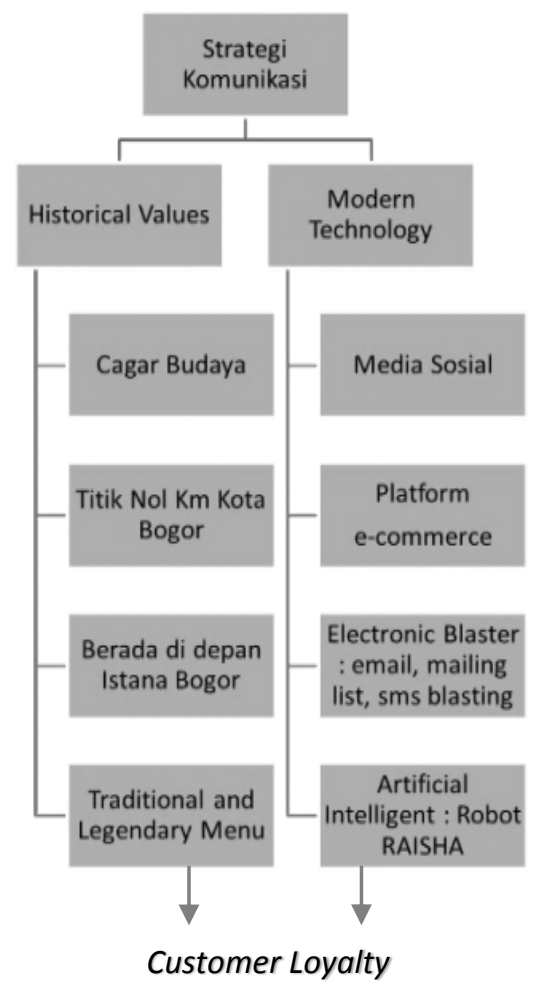

\section{Loyalitas Pelanggan HSTH}

Fatian \& Gholamian (Pratminingsih, 2013), mengungkapkan bahwa customer loyalty terjadi ketika pelanggan membeli produk atau jasa secara berulang dan bersikap positif terhadap barang dan jasa dari perusahaan. Berdasarkan data dan hasil wawancara, sejak beroperasinya, HSTH memiliki dua jenis segmen pelanggan yakni FIT (Free Individual Traveller) dan MICE. Dari tabel 4.1 tentang tingkat hunian (occupancy rate) HSTH, terlihat bahwa sejak tahun 1998 terus mengalami peningkatan, meskipun terjadi penurunan di beberapa tahun, namun tidak signifikan. Oliver (1997), Blut et al (2007) mengatakan bahwa loyalitas pelanggan dibangun dalam empat tahapan (four-stage loyalty model), yakni kognisi (cognitive loyalty), afeksi (affective loyalty), dan konasi (conative loyalty), dan action loyalty yang berlangsung secara siklis.

Pada tahap pertama, para pelanggan loyal terhadap brand berasal dari informasi brand itu sendiri, seperti kualitas, harga, penawaran. Artinya, pelanggan mendapat informasi dari berbagai saluran komunikasi dan event yang disampaikan oleh HSTH, juga melalui informasi dari pelanggan lain yang telah merasakan manfaat fasilitas di HSTH. Tahap kedua yaitu affective loyalty, loyalitas yang berkaitan dengan sikap tertentu terhadap sebuah brand. Sikap sendiri merupakan fungsi dari kognisi, misalnya munculnya harapan (expectation) terhadap sebuah brand (Blut et al, 2007). Sikap dan harapan yang terpenuhi maka akan melahirkan kepuasan (satisfaction) atas pelayanan yang diberikan oleh HSTH. Oliver (1993) menyatakan bahwa kepuasan sebagai "the consumer's fulfillment of response, the degree to which the level of fulfilment is pleasant or unpleasant."

Tahap ketiga, conative loyalty, menunjukkan bahwa loyalitas ditunjukkan dengan adanya keinginan untuk melakukan tindakan mengulang untuk membeli (repurchase) atau dalam hal ini adalah mengulang untuk menggunakan jasa fasilitas HSTH. Dari tabel 4.1, terlihat di tahun 2004, 2006, 2013, 2014, dan 2015 mengalami penurunan dalam tingkat hunian (occupancy rate) HSTH. Hal ini diakui oleh divisi Marketing dan juga sub Divisi PR \& Promotion bahwa di tahun tersebut HSTH mengalami penurunan revenue yang disebabkan karena tingkat kompetisi yang cukup tinggi dalam bisnis perhotelan di Kota Bogor. Oleh karenanya, maka pihak manajemen memutuskan untuk melakukan pertemuan tingkat manajerial setiap pekan sekali yaitu setiap hari Senin untuk segera memberikan respons dan evaluasi serta mempersiapkan strategi dan taktik pesan secara cepat sehingga segera sampai kepada para pelanggan. Pihak PR HSTH juga mengakui bahwa terkadang terjadi complain dari 
pelanggan, misalnya terkait kamar, atau barang hilang atau ketinggalan, atau pelayanan lain. Bagian GRO akan memantau komentar para pelanggan melalui guest comment baik secara online (review pada Google, Traveloka, dan email blaster) atau melalui offline, yaitu on the spot pada saat keluhan disampaikan dan kemudian ditindaklanjuti oleh pihak terkait dengan segera. Pihak manajemen melalui GRO akan mengirimkan apologize letter kepada pelanggan melalui email pribadi pelanggan.

Tahap keempat, action loyalty, loyalitas tahap ini menunjukkan bahwa tidak semua maksud atau tujuan serta merta diikuti dengan keinginan untuk kembali membeli produk yang sama. Artinya bahwa ketiga tahapan sebelumnya (kognitif, afektif, dan konatif) memberikan kemungkinan untuk siap melakukan tindakan (dalam konteks ini tentu 'membeli' kembali jasa atau fasilitas HSTH). Kesiapan tersebut disertai oleh kemauan (willingness) para pelanggan untuk mencari penawaran-penawaran lain yang menarik meskipun pada akhirnya pelanggan melakukan pembelian kembali (dalam konteks HSTH adalah para repeater seperti yang tercantum dalam tabel 4.2. Dalam tabel tersebut, terlihat untuk segmen MICE, pelanggan HSTH yang terutama berasal dari instansi atau perusahaan yang memanfaatkan pelayanan HSTH untuk acara pertemuanpertemuan skala kecil, sedang, maupun besar. Repeater utamanya berasal dari instansi pemerintah tingkat kementerian, seperti Kementerian Pertanian, Kementerian Pedesaan, Kementerian BUMN, dan Kementerian Pendidikan dan Kebudayaan.

Menurut bagian PR, Adhysti mengatakan bahwa dinamika dalam bisnis perhotelan tentu saja menjadi bagian dari pengelolaan dan konsekuensi, diakuinya bahwa revenue HSTH dalam dua tahun terakhir mengalami penurunan meskipun tidak signifikan. Hal ini tentu menjadi perhatian semua divisi untuk mempertahankan loyalitas pelanggan di tengah kompetisi yang semakin kuat dalam dunia bisnis perhotelan, khusunya di Kota Bogor.

Berdasarkan data yang berhasil diperoleh dari bagian GRO yang memantau review dari para pelanggan dari beberapa corporate, beberapa kekuatan yang dimiliki oleh HSTH yang mendorong para pelanggan tersebut melakukan repeating dalam menggunakan layanan HSTH adalah:

1 Lokasi dekat dengan pusat kota. Hal ini menjadi pertimbangan utama bagi para corporate untuk melaksanakan kegiatan pertemuan di HSTH, di samping itu akses tol cukup strategis jika menggunakan kendaraan pribadi.

2 Lokasi Hotel dekat dengan Istana Bogor. Istana Bogor merupakan tempat pariwisata iconic di Kota Bogor dan juga merupakan bangunan peninggalan zaman kolonial Belanda, sehingga memiliki keselarasan identitas dengan HSTH. Selain memiliki nilai historis, tempat ini juga terjangkau oleh masyarakat luas, sehingga menjadi daya tarik tersendiri baik masyarakat umum, ataupun tamu-tamu pengunjung hotel.

3 Lokasi hotel dekat dengan stasiun kereta api Bogor. Bagi beberapa corporate, terutama yang dari luar kota Bogor seperti Jakarta, bagi pelanggan yang tidak menggunakan kendaraan pribadi maka akses kereta api menjadi alternatif transportasi. HSTH cukup strategis berada tidak jauh dari Stasiun Bogor, kurang lebih berjarak 4 kilometer.

4 Fasilitas Hotel. Bagi sebagian corporate, fasilitas untuk acara pertemuan dinilai memadai karena dapat menyesuaikan kebutuhan mereka. HSTH mampu memberikan alternatif ruang pertemuan baik yang berkapasitas kecil, sedang, maupun besar (hall) sehingga sangat efisien bagi kebutuhan penyelenggaraan kegiatan perusahaan, misalnya ketika acara dilaksanakan selama tiga hari, hari pertama menggunakan hall kemudian hari kedua dan ketiga menggunakan ruangruang yang lebih kecil yang masih dalam satu area.

5 Hidangan Menu yang Bervariasi. HSTH menawarkan berbagai menu baik legendaris, tradisional (nusantara), dan internasional. Menu-menu favorit tamu-tamu asing seperti oxtail soup, yaitu sop iga yang telah melegenda sejak jaman kolonial, sejak HSTH bernama Bellevue. Untuk memberikan layanan bagi tamu yang menginginkan membawa oleh-oleh khas HSTH, maka pelanggan dapat mendapatkannya di Restoran Klappertaart Huiz (salah satu business unit di bawah Salak Hospitality) yang menawarkan suguhan khas klappertart dengan berbagai variasi rasa.

6 Kebersihan Kamar. Aspek ini sangat menjadi perhatian para pelanggan HSTH. Kebersihan dan fasilitas kamar dirasakan membuat mereka nyaman untuk tinggal dan jika ada keluhan maka pihak hotel akan segera merespon dengan cepat. HSTH memberikan pilihan kamar hotel untuk nonsmoking dan smoking room sehingga para pelanggan dapat terpenuhi kenyamanannya 
Implikasi secara manajerial terkait dengan loyalitas pelanggan HSTH saat ini tentu semakin kompleks karena dipengaruhi berbagai faktor yang telah diulas di atas. Loyalitas terhadap brand atau perusahaan harus dilakukan secara berkesinambungan (sustainable) dan menyesuaikan dengan konteks kebutuhan pelanggan yang harus terus di-update oleh perusahaan melalui bagian-bagian atau divisi yang saling bersinergi, dalam konteks HSTH adalah bagian Marketing dan fokus pada PR \& Promotion terutama terkait pengolahan pesan-pesan yang diformulasikan dalam berbagai saluran komunikasi (media) maupun event. Fokus pada revenue dalam sector MICE masih dapat menjadi prioritas bagi HSTH, karena sebagaimana dijelaskan oleh bagian PR \& Promotion bahwa kekuatan HSTH ada pada layanan MICE yang memberikan alternative ruangan pertemuan yang memadai dengan jumlah yang mencukupi.

\section{SIMPULAN}

Hospitality industry merupakan bisnis yang sangat dinamis. Dinamika ini tentu harus diiringi dengan penerapan strategi komunikasi efektif, terutama strategi komunikasi pemasaran (integrated marketing communication) melalui serangkaian pengelolaan pesan melalui saluran komunikasi yang sesuai untuk membangun dan memepertahankan kepuasan dan loyalitas pelanggan. Hotel Salak The Heritage melalui PR \& Promotion Department dan Divisi Sales \&Marketing secara kolaboratif merancang dan melaksanakan berbagai program dalam strateginya untuk mempertahankan loyalitas pelanggan. Strategi yang dilakukan merupakan implementasi dan penjabaran dari dari visi, misi, tujuan, dan motto perusahaan.

Dengan tagline "where historical values and modern technology meet", maka Hotel Salak memiliki distingsi dalam melakukan strategi yang mencakup historical values dan modern technology untuk terus mempertahankan pelanggan (customer repeater), terutama dari kelompok corporate yang memanfaatkan layanan MICE (meeting, incentive, convention, exhibition) yang dimiliki oleh HSTH.
Pertumbuhan hotel yang semakin pesat tentunya semakin mendorong HSTH untuk senantiasa mengevaluasi dan melakukan riset lapangan terkait dengan apa yang diinginkan oleh pelanggan. Bisnis berbasis teknologi melalui penggunaan media sosial, artifical intelligent, dan e-commerce masih efektif untuk strategi pemasaran dalam konteks sekarang. Selain itu, promosi melalui program special events harus dikemas lebih menarik lagi bagi pelanggan, sehingga identitas HSTH sebagai hotel bernilai sejarah tetap dapat diterima masyarakat di tengah kompetisi pertumbuhan hotel yang semakin pesat khususnya di Kota Bogor sebagai salah satu destinasi wisata di Indonesia.

\section{DAFTAR PUSTAKA}

Akavaram, V., Bradley, L. M., Lei, L. Y., \& Louie, L. (2018). Tailored interpersonal communication platform management. Google Patents.

Belasen, A. T. (2008). Corporate Communication: A Competing Value Perspective, Los Angeles: Sage Publications.

Buttle, F. (2004). Customer Relationship Management: Concept and Tools, (edisi terjemahan) Jakarta: Bayumedia Publishing.

Cornelissen, J. (2008). Corporate Communication: A Guide to Theory and Practice, Los Angeles: SAGE Publications.

Cutlip, S. M., Center, A. H., \& Broom, G. M. (2009). Effective Public Relations, Jakarta: Kencana Prenada Media Group.

Effendy, O. U. (2005). Ilmu Komunikasi Teori \& Praktek, Bandung: Remaja Rosda Karya.

Herdiansyah, H. (2010). Metodologi Penelitian Kualitatif untuk IImu-IImu Sosial, Jakarta: Penerbit Salemba Humanika.

Kasali, R. (2008). Manajemen Public Relations, Konsep dan Aplikasinya, Jakarta: PT Pustaka Utama Grafiti. 
Kriyantono, R. (2008). Teknik Praktis Riset Komunikasi, Jakarta: Kencana Prenada Media Group.

Kriyantono, R. (2017). Teori-teori Public Relations Perspektif Barat \& Lokal, Jakarta: Kencana Prenada Media Group.

Kotler, P., \& Keller, K. L. (2012). Manajemen Pemasaran, Jakarta: Erlangga.

Mulyana, D. (2007). IImu Komunikasi Suatu Pengantar, Bandung: PT Remaja Rosdakarya.

Rangkuti, F. (2006). Measuring Customer Satisfaction, Jakarta: PT Gramedia Pustaka Utama.

Ruslan, R. (2007). Manajemen Public Relations \& Media Komunikasi. Jakarta: PT. Raja Grafindo Persada.

Wiyasha, I. (2010). Akuntansi Perhotelan, Yogyakarta: Andi Offset.

Al Khomsa, F. (2015). Strategi Komunikasi Pemasaran Kafe Kopmil Ping $2 \mathrm{U}$ Pekanbaru dalam Mempertahankan Loyalitas Konsumen, JoM FISIP 2(2), 1-15.

Demirciftci, T., \& Kizilirmak, I. (2015). Strategic Branding in Hospitality: Case of Accor Hotels. Journal of Tourismology, 2(1), 5058.

Juniardi, A., Haerani, S., \& Munir, A. R. (2018). Pengaruh Strategi Bauran Pemasaran terhadap Kepuasan dan Loyalitas Pelanggan Hotel Novotel Makassar Grand Shayla City Centre, Hasanuddin Journal of Applied Business and Entrepreneurship, 1(4), 52-64.

McMullan, R., \& Gilmore, A. (2008). Customer Loyalty: An Empirical Study, European Journal of Marketing, 42(9), 1084-1094.

Pratminingsih, S. R., Lipuringtyas, C., \& Rimenta, T. (2013), Factors Influencing Customer Loyalty Towards Online Shopping, International Journal of Trade, Economics and Finance, 4(3), 104-110.

Poovalingam, K., \& Veerasamy, D. (2007). The Impact of Communication on Customer Relationship Marketing among Cellular
Service Providers, Alternation, 14(1), 86119.

Ruliana, P., \& Dwiantari, R. (2015). Strategi Public Relations Hotel dalam Membentuk Citra Objek Wisata, Jurnal Komunikasi ASPIKOM, 2(4), 255-271.

Umami, Z. (2015). Social Strategy pada Media Sosial untuk Promosi Pariwisata Daerah Istimewa Yogyakarta, Jurnal Interaksi, 4(2), 195-201

Van Riel, C. B. M., \& Fombrun, C. J. (2007). Essentials of Corporate Communications. New York: Routledge Taylor \& Francis Group. ISBN 13: 978-0-203-39093-1

www.kemenpar.go.id.

www.hotelsalak.co.id 